\title{
The Impact of a Cooperative Learning Program on the Academ- ic Achievement in Mathematics and Language in Fourth Grade Students and its Relation to Cognitive Style
}

\author{
Mery Luz Vega ${ }^{*}$, Christian Hederich M. ${ }^{2}$ \\ ${ }^{1}$ Colegio José Martí IED. Secretaría de Educación de Bogotá, Colombia \{mlvega@redp.edu.co\} (iD) \\ 2Universidad Pedagógica Nacional, Colombia \{mlvegav@unal.edu.co\} (1) \\ Received on 24 January 2015; revised on 26 January 2015; accepted on 11 April 2015; published on 15 July 2015
}

DOI: 10.7821/naer.2015.7.124

\begin{abstract}
This study is expected to determine the impact of a program based on the cooperative learning methodology. This, in comparison to a traditional learning situation in both mathematics and language achievement. The study was carried out on a group of fourth grade students of primary school. In addition, it tried to find the differential impact according to the cognitive style in the field dependence-independence dimension. This work was carried out with 76 students of the Colegio José Martí I.E.D. (BogotáColombia) ranging from 8-12 years of age. The control group received a traditional teaching methodology and the experimental group received the cooperative learning program, composed of 35 sessions (from July to November 2009). All the participants were tested in mathematics and language performance, before and after the intervention. All of them were tested in cognitive style as well. The results suggested that the cooperative learning methodology benefited importantly the academic achievement of the students in mathematics in contrast to the competitive and individualist situations. The results also suggested that the three cognitive style groups were positively affected from the cooperative learning situation. These results were not found in the language area.
\end{abstract}

KEYWORDS: COOPERATIVE LEARNING, COGNITIVE STYLE, TEACHING METHODOLOGIES

\section{INTRODUCTION}

One of the main interests of pedagogy has been to provide evidence on how effective several didactic strategies are in different types of students. This study researched the benefits of cooperative learning and its impact on student performance related to their cognitive style.

Cooperative learning introduces a breakthrough in the social structure of learning situations. Within this field of research, three types of academic situations have been identified: individualist, competitive and cooperative situations. Different studies have indicated that cooperative learning is the situation that most positively impacts the achievement of high school and university students, as well as their social skills and their

*To whom correspondence should be addressed:

Carrera 8 N ${ }^{\circ}$ 48-24 Apto. 202, Bogotá, Colombia. psychological health (Johnson \& Johnson, 1999, 2009; Johnson, Johnson, \& Smith, 2014). Furthermore, these studies have shown that learning based on cooperative structure could be a useful tool for all ages, subjects and students.

Research on the topic of cognitive styles has shown the existence of different learning modes and approaches to knowledge; these different modes deeply affect individual performance and the approaches to the task. Also, research has pointed out that most educational systems are structured in order to benefit some types of cognitive learning above others (Hederich, 2007).

\section{CONCEPTUAL ASPECTS}

\subsection{Cooperative learning}

From a social perspective, three academic learning environments have been identified: competitive, individualist and cooperative environment. These environments are structured differently. They generate interactions among students which affect the learning dynamic itself, as well as the nature of the students' interactions.

Competitive learning situations try to determine who the best in a group is. Even though the learning goals are objective, or are general, few students achieve them. Thus, in this environment the student's personal success is born from the failure of the rest of the group. Only few students achieve the highest score. For this reason, the self-esteem of the students with lowest scores are affected by a feeling of defeat. This phenomenon is interpreted by Arias, Roca \& Estupiñán (2003) as a negative interdependence in the achievement of goals, since students perceive that their achievements are related to other students' failures.

The individualist environment shows that students work independently on their own goals, at their own pace, based on a pre-established criteria (Arias et al., 2003). In this environment, the teacher asks the students to work by themselves in the achievement of their goals without interacting with their classmates. Consequently, each student focuses on a particular interest and values only his own successes and failures but not the successes and failures of the others. Here, the achievement of the objectives is not related to the work of the other students, so there is not any learning goal interdependence.

Cooperative learning appears as an option to level the deficiencies that competitive and individualistic environments 
have. In a cooperative learning situation, students work together in small teams in order to ensure that each of the students in the group learns. In this situation, the students are in an interaction, which implies that the learning goals are achievable only as a group not as individuals, this is known as positive interdependence (Johnson et al., 2014).

As schools present more and more heterogeneous populations, cooperative learning becomes important and useful because it can help diversity become a resource instead of a problem (Slavin, 1995). As a matter of fact, cooperative learning methods not only take advantage of the differences between students, but they often require such differences. The diversity that gravely annoys traditional teaching is considered something positive in favor of the teacher (Monereo \& Duran, 2002).

The group objective in cooperative learning is to maximize the whole team learning, motivating students to try harder and obtain better results than they would have if they were working separately. Besides, students realize that if one of them fails, all of them will flunk as well. In cooperative learning, each member assumes his own duty and makes others face their responsibilities too; at the same time, the team works together in order to obtain joint results. In addition, all the members develop special forms of interpersonal relationships in order to coordinate their work and achieve their goals. All the members analyze their performance, their teamwork and the achievement of their objectives (Johnson, Johnson, \& Holubec, 2008).

\subsection{Effects of cooperative learning}

Cooperative learning has been a well-used tool by teachers all over the world and it has had a long and successful history of research. Johnson et al. (2008) have widely researched cooperative learning and they have found encouraging results about its efficacy.

One of the most important conclusions is that cooperation is a human effort that affects several fields at the same time, for instance: academic achievement, thought process, interpersonal relationships and psychological health (Duxbury \& Tsai, 2010; Haiyan, 2014; Hossain \& Ahmad, 2013; Jiang, 2014; Johnson, Johnson, \& Smith, 2014; Slavin, Sheard, Elliot, Chambers \& Cheung, 2013).

Regarding academic achievement, research has shown some advantages in cooperative learning when it's compared to competitive and individualistic learning (Ahmad \& Mahmood, 2010; Herman, 2013; Johnson et al., 2014; Ning \& Hornby, 2014; Pons, Prieto, Lomeli, Bermejo, \& Bulut, 2014; Sears \& Pai, 2012). Also, research has demonstrated advantages in some specific areas such as reading comprehension (Khan \& Ahmad, 2014; Zuo, 2011), writing (AbdelWahab Mahmoud, 2014), Biology (Muraya \& Kimano, 2011) and Mathematics (Lavasani \& Khandan, 2011).

In spite of that, the significance and limitations of this methodology in each area of knowledge have not been clearly defined, neither in age, kind of task, cognitive style or social skills. Although cooperative learning appears to be promising pedagogic proposal, it has not been either spread nor applied in Colombian schools.

\subsection{Cognitive styles}

As it was previously stated, the diversity of each group of students is a challenge for teachers to assume. Individual differences are almost always seen as a difficulty and instead of strengthening them, teachers tend to homogenize the skills of the students, with the intention of improving the outcomes.

However, it is possible to change the approach of the individual differences taking advantage of the specific characteristics of each student, so, it favors the team's learning. According to that, it is important to know the different ways of learning and of approaching the knowledge that the students have, that is to say: their cognitive styles.

One of the most studied dimensions related to cognitive styles is field dependence-independence (FDI), proposed by Herman Witkin more than fifty years ago (Witkin, Moore, Goodenough, \& Cox, 1977). From this perspective, cognitive differences are established between the two poles: the field dependence and the field independence. These differences are identified in aspects such as perception and information processing when performing cognitive related tasks.

Field independent individuals tend to process information in an inductive and analytical manner. This allows such individuals to take information and decompose it, as well as restructure it according to their own individual necessities. Field independent individuals are characterized by permitting neither contextual factors nor external criteria to influence them (López \& Triana, 2013). Field independent people are autonomous and usually distant from social interaction, therefore, they prefer to work by themselves rather than in groups.

In contrast, field dependent individuals tend to process information in a general and context influenced manner. Since they are more sensitive to external influences, field dependent individuals often preserve the structure in which information was introduced by adding new concepts to the initial reference. Field dependent subjects present positive qualities in the social interaction stage; they are willing to relate to others and work as a team.

Field dependent and field independent individuals also differ on learning efficacy, learning roles, preferences and motivations towards specific knowledge areas. Specifically, it has been found that field dependent students achieve lower academic scores than their counterparts at all levels of the educational system (Hederich, 2007).

These findings have been attributed to the fact that the educational system favors the achievements of field independent students over field dependent ones (Hederich, 2007). This inequality points out the importance of adapting teaching methodologies and evaluating criteria to the inherent nature of field dependent subjects.

\subsection{Cooperative learning and cognitive styles}

Making note of what Hederich (2007) have stated, it is necessary to develop teaching methodologies that benefit every cognitive style. Cooperative learning becomes an interesting alternative because it implies a change in the learning interaction that allows all students to learn at the same level, without isolating students with a different cognitive tendency.

Some works like Tinajero, Castelo, Guisande \& Páramo (2011) and Prayekti (2015) demonstrate that it is possible that alternative teaching methods such as cooperative learning benefit students with different stylistic polarities. Specifically, Peklaj (2003) points out the potential effects and advantages of cooperative learning on field dependent students compared to competitive and individualistic methodologies. 
The study of Peklaj (2003) suggests that cooperative learning mostly benefits the field dependent students. This study evaluated the effects of cooperative learning versus competitive and individualistic learning on achievement according to the cognitive style of the students. The research was carried out with fifth grade students and evaluated math and language (Slovenian) achievements. The author found positive effects of cooperative learning compared to traditional learning on both, math and language areas, but the advantages were greater for the field dependents; a fact that could demonstrate their preference to social situations.

However, other research such as Guerra \& Orozco (2009) shows that cooperative learning possibly has major effects on field independent students. These authors looked into the impact of three methodologies: individualist, semi-cooperative (pairs) and cooperative on math problem resolutions in sixth grade students. The outcome showed that the cooperative learning group performance increased considerably compared to semicooperative and individualist group performance. Regarding the cognitive style, an interaction between teaching methodology and cognitive style were found. This permitted that, in cooperative learning situations, independent and intermediate subjects benefited. In semi-cooperative learning only independent subjects benefitted and nobody benefited in the individualist methodology.

The study developed by Vidal (2012) did not provide evidence in favor of any of the two cognitive styles but it confirmed the superiority of cooperative learning compared to traditional teaching methodologies. The implications of cooperative learning on math academic achievements in fifth and sixth grade students were inquired in this study. Vidal (2012) found that the impact of cooperative learning was positive mainly on sixth grade subject performance.

Other research like Moreno (2011) and García (2012) did not show any effect related with cognitive style either. Nevertheless, slight implications of cooperative learning on math performance and written language were evidenced.

Although the studies mentioned were inconclusive, they do provide crucial breakthroughs for analyzing the advantages that cooperative learning introduces compared to individualist and competitive methodologies. As mentioned by Vega, García \& Vidal (2013), the major effects of this methodology have been found in mathematics, mainly in fifth and sixth grade than in younger students. Regarding cognitive style, the outcomes are contradictory and therefore are not conclusive.

All these works reveal that cooperative learning could be a teaching methodology that favors students' achievement and potentially could make up for the deficiencies that educational systems have because of their design to only take into account the skills of the field independent student .

This study was carried out with the purpose of providing empirical evidence in favor of cooperative learning as a pedagogic alternative that can offer equal academic benefits for students regardless of their cognitive style.

\section{METHODOLOGY}

\subsection{Design}

A quasi-experimental design with pre and post-test was performed in two previously conformed groups: quasiexperimental and quasi-control.

\subsection{Participants}

This study was done with 76 fourth grade students of the José Martí I.E.D. School, 35 girls and 41 boys. These students belonged to 2 different groups of the school in different shifts and branches. The control group had 43 participants, 22 girls and 21 boys; the experimental group had 33 participants, 13 girls and 20 boys. The participants' ages ranged from 8 to 12 years, with a mean of 9.5 years.

\subsection{Measurement instruments}

Cognitive style: EFT (Embedded Figure Test). This is an instrument used to determine cognitive styles in the field independence-dependence dimension. The statistical analyses have shown an excellent internal consistence with an Alpha corrected value, according to Spearman-Brown formula, of 0,94 (Hederich, 2007).

Academic achievement: "Prueba Saber de Matemáticas y de Español” (Test Knowing Mathematics and Spanish) 2003 (pretest) and 2005 (post-test). These are tests which have been used in Colombia in order to evaluate the achievement level reached by $3^{\text {rd }}, 5^{\text {th }}, 7^{\text {th }}$ and $9^{\text {th }}$ grade students. For this work, the tests used were the 2003 and 2005 years in the topics already mentioned for the $3^{\text {rd }}$ grade (MEN-ICFES, 2003).

The reliability of the tests found in this study, in both pre-test and post-test, was too low. For this reason it was necessary to delete several items because they did not have statistical correlation. After this procedure an acceptable reliability was reached: Cronbach's Alpha of 0,62 in math and 0,65 in language, in pretest and post-test.

\subsection{Procedure and experimental task}

Initially, a diagnostic evaluation was made using the cognitive style, math and language tests. After that, the students were informed about their scores in all these tests, and about the objectives and methodology of the study, characteristics and components of cooperative learning, and the context and management of the collected information.

In order to carry out the experimental task, the following guidelines proposed by Arias et al. (2003) about the Learning Together program were taken into account:

First of all, 2 groups of 4 students, 8 groups of 3 students and one group of 2 students were formed. Each group chose an identifying name, a slogan and a song. Each group was informed about how to organize the classroom, furniture and material for the cooperative work. Preparation of the classes and materials were administered in order to promote Positive Interdependence and Individual Responsibility between students.

35 sessions were completed between July and November 2009. The sessions were executed in the areas of math, language, natural sciences and social sciences. The first three sessions were designed to introduce cooperative learning and the following sessions were divided in the areas mentioned previously; some of them had evaluations, group processing and cooperative skills training (Arias et al. 2003).

From the fourth session cooperative work started completely including monitoring and intervention in the groups. Besides constant accompaniment, support and orientation, social and cooperative conducts were also molded.

A structured form of observation was used in order to evaluate each participant's work within the group. Evaluation which valued factors such as idea contribution, quality of work, 
partners' support, and group orientation was made together as a group.

Finally, math and language post-tests were given. The information was tabulated, recorded and analyzed through SPSS Version 15.0 statistical software.

\section{RESULTS}

\subsection{Cognitive characterization}

The general scores in EFT were between 0 and 29 points. The mean was 9,5, the standard deviation was 6,3 , and the mode was 7.

The mean in EFT was higher in the control group $(10,3)$ than in the experimental group $(8,4)$. However, The t test showed that there were no significant differences between both groups $(t=1,28 ; p=0,20)$. In order to perform an analysis co-variance, the group was divided into three equal subgroups of cognitive style: field dependent (FD), intermediate (I) and field independent (FI).

\subsection{Initial conditions}

\subsubsection{Math}

General scores in math pre-test were between 0 and 12 points, with a maximum score of 15 . The mean was 5,68 and the mode was 5.

The median was the same for both groups (5). For that reason it is possible to assume that they were similar in this area at the beginning of the study. The mean was almost the same (5,70 y $5,67)$ and the Student's t-test showed that there were no significant differences between both groups $(t=0,48$; $p=0,96)$.

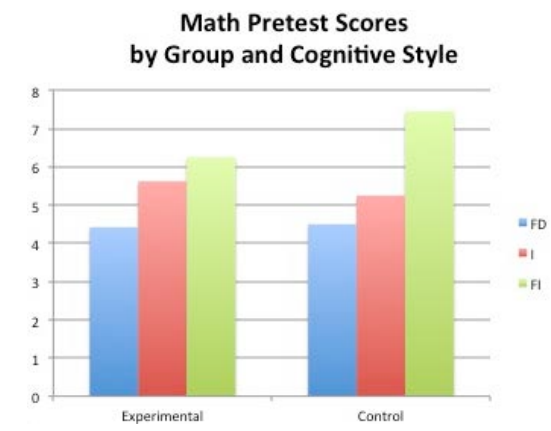

Figure 1. Score distribution for the math pre-test according to cognitive style

In figure 1 it is possible to observe that both groups had similar performances at the beginning of the study but there were differences related to cognitive style. Actually, the dependent group had low scores; the intermediate group had medium scores and the independent group recorded high scores. The ANOVA test showed significant differences linked to style groups $(F=5,06 ; p=0,009)$. Specifically, the post-hoc analysis found a significant difference between field independents (FI) and field dependents (FD) in the DSH test of Tukey $(\mathrm{p}=0,006)$.

\subsubsection{Language}

General scores in language pre-test were between 0 and 12 points, with a maximum score of 15 . The mean was 5,64 and the mode was 6.
In Figure 2 it is possible to observe that the participants of the control group performed better at the beginning of the study in comparison to the experimental group. Specifically, the mean in language pre-test of the control group was 6,4 and in the experimental group it was 4,5 . The t-test showed that the control group had a higher performance in this area at the beginning of the experiment $(\mathrm{t}=3,1 ; \mathrm{p}=0,003)$.

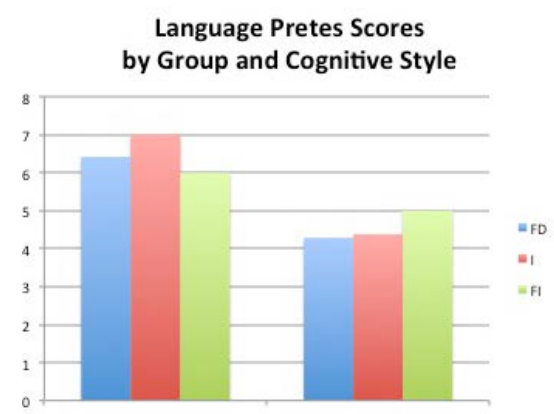

Figure 2. Score distribution for the language pre-test according to cognitive style

Besides, it is possible to perceive that there was no performance difference according to cognitive style in any of the groups. The ANOVA test demonstrated that there were no significant differences between the three groups of cognitive style $(F=0,36 ; p=0,69)$.

\subsection{Intervention impact}

\subsubsection{Math}

Post-test general scores in math were between 1 and 14 points, with a maximum of 15 .The mean was 5,6 and the mode was 5 points.

After examining the joint effect of cooperative learning methodology and cognitive style on the math post-test, a univariate analysis of covariance was carried out using the data from the pre-test as a covariable. The results provide a model with a significant capability to predict the math post-test (F= $5.48, \mathrm{p}<0.001)$ taking into account the methodology (GROUP) and the cognitive style (NEFT). This model was able to explain 28.3\% of post-test variance. See Table 1 and Figure 3.

Table 1. Analysis of variance data in math post-test according to methodology (GROUP) and cognitive style

\begin{tabular}{|c|c|c|c|c|c|}
\hline \multicolumn{6}{|c|}{ Intersubject Efects Test } \\
\hline \multicolumn{6}{|c|}{ Dependent variable: MATH POSTEST SCORES } \\
\hline & $\begin{array}{c}\text { Square Sum } \\
\text { Type III }\end{array}$ & gl & $\begin{array}{c}\text { Cuadratic } \\
\text { Mean }\end{array}$ & $\mathrm{F}$ & $\mathrm{p}$ \\
\hline Corrected model & $180,598_{\mathrm{a}}$ & 6 & 30,1 & 5,483 & $\begin{array}{c}<0,001 \\
* *\end{array}$ \\
\hline Intersection & 270,202 & 1 & 270,202 & 49,216 & $\begin{array}{l}<0,001 \\
* *\end{array}$ \\
\hline $\begin{array}{l}\text { MATH PRETEST } \\
\text { SCORES }\end{array}$ & 8,114 & 1 & 8,114 & 1,478 & 0,229 \\
\hline GROUP & 134,245 & 1 & 134,245 & 24,452 & $\begin{array}{l}<0,001 \\
\quad * *\end{array}$ \\
\hline COGNITIVE & 19,704 & 2 & 9,852 & 1,794 & 0,175 \\
\hline
\end{tabular}




\section{STYLE (CS)}

\begin{tabular}{lrrrrr} 
GROUP * CS & 2,361 & 2 & 1,18 & 0,215 & 0,807 \\
Error & 340,387 & 62 & 5,49 & & \\
Total & 2748 & 69 & & & \\
Total corrected & 520,986 & 68 & & & \\
\hline
\end{tabular}

a. R Square $=, 347(\mathrm{R}$ Square corrected $=, 283)$

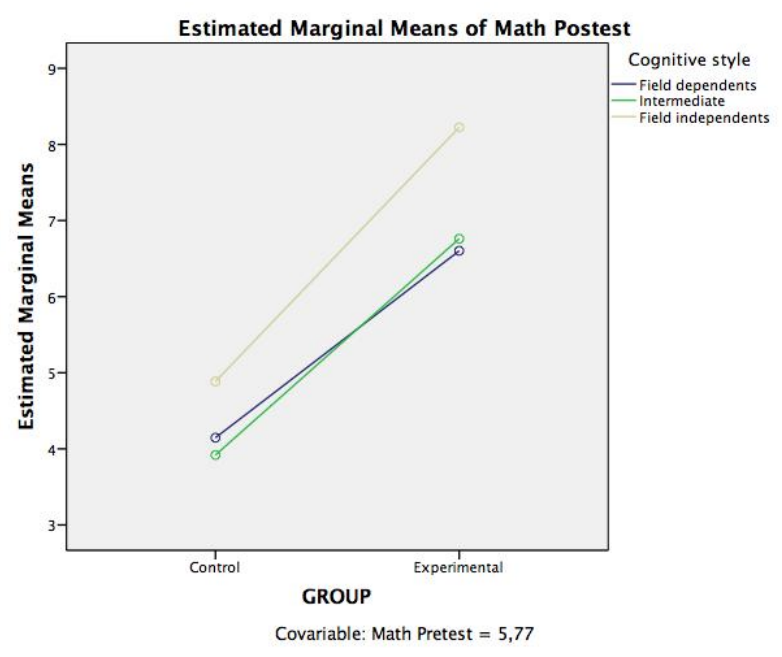

Figure 3. Estimated marginal means of math post-test according to methodology (GROUP) and cognitive style

Significant differences in favor of the experimental group were observed $(\mathrm{F}=24,4 ; \mathrm{p}<0,001)$; this effect might be exclusively attributed to the cooperative learning program. This is possibly the most important finding because it provides evidence to the claim that cooperative learning is thoroughly superior to traditional methodologies.

With regards to cognitive style, the tests did not show any effect of this factor $(\mathrm{F}=1,79, \mathrm{p}=0,17)$ nor of its interaction with the treatment either. Given the fact that cognitive style was related to math performance in pre-test and that this relation disappeared in post-test when it's controlled by the co-variable, it is possible to assume that the benefic effect of cooperative learning was equivalent for all three style groups.

\subsubsection{Language}

In language general post-test scores were between 0 and 14 points, with a maximum of 15 .The mean was 8,3 and the mode was 8 points.

After examining differences in language post-test in both groups, the results prove that the control group kept on being superior to the experimental group, with an average of 8,4 , while the experimental group had an average of 8,0. However, the Student's t- test showed that those differences are not significant between groups $(t=0,58 ; p=0,56)$.

A univariate analysis of co-variance was carried out using the language pre-test data as co-variable in order to prove whether there were differences that could be attributed to treatment. The results allowed a model with significant capability of the prediction in language pre-test $(\mathrm{F}=4,48, \mathrm{p}<0.001)$ to be constructed taking into account methodology (GROUP) and cognitive style (NEFT). This model was able to explain 23,5\% of post-test variance. See Table 2 and Figure 4.

Table 2. Analysis of variance data in language post-test according to methodology (GROUP) and cognitive style

\begin{tabular}{|c|c|c|c|c|c|}
\hline \multicolumn{6}{|c|}{ Intersubjects Efects Test } \\
\hline \multicolumn{6}{|c|}{ Dependent variable: LANGUAGE POSTEST SCORES } \\
\hline & $\begin{array}{l}\text { Square Sum } \\
\text { Type III } \\
\end{array}$ & $\mathrm{gl}$ & $\begin{array}{c}\text { Cuadratic } \\
\text { Mean } \\
\end{array}$ & $\mathrm{F}$ & $\mathrm{p}$ \\
\hline Corrected model & $184,278_{\mathrm{a}}$ & 6 & 30,713 & 4,48 & $0,001 *$ \\
\hline Intersection & 409,476 & 1 & 409,476 & 59,728 & $\begin{array}{c}<0,001^{*} \\
*\end{array}$ \\
\hline $\begin{array}{l}\text { LANGUAGE } \\
\text { PRETEST SCORES }\end{array}$ & 113,474 & 1 & 113,474 & 16,552 & $\begin{array}{c}<0,001^{*} \\
*\end{array}$ \\
\hline GROUP & 1,913 & 1 & 1,913 & 0,279 & 0,599 \\
\hline $\begin{array}{l}\text { COGNITIVE STYLE } \\
\text { (CS) }\end{array}$ & 8,421 & 2 & 4,21 & 0,614 & $4 \quad 0,544$ \\
\hline GROUP * CS & 45,509 & 2 & 22,755 & 3,319 & 0,043* \\
\hline Error & 425,055 & 62 & 6,856 & & \\
\hline Total & 5401 & 69 & & & \\
\hline Total corrected & 609,333 & 68 & & & \\
\hline
\end{tabular}

a. $\mathrm{R}$ Square $=, 302(\mathrm{R}$ Square corrected $=, 235)$

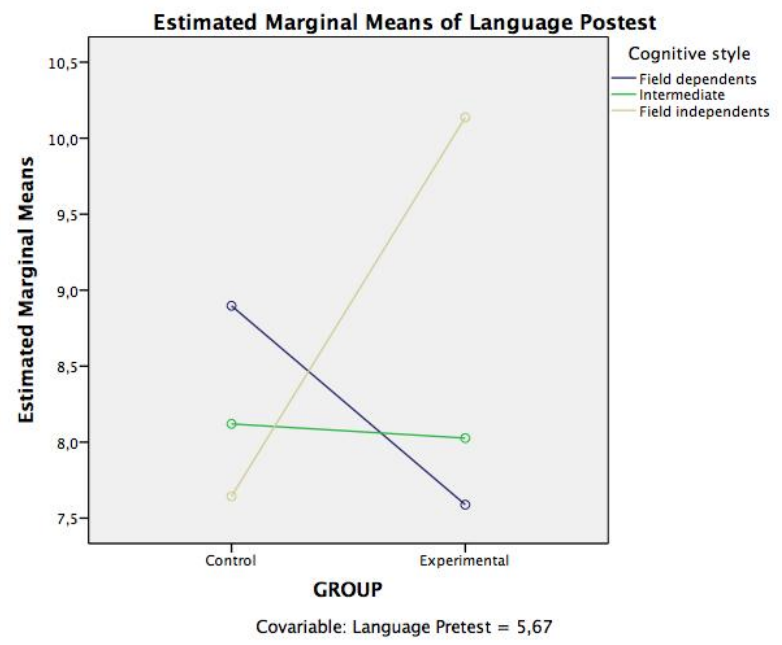

Figure 4. Estimated marginal means of Language Postest Scores according to methodology (GROUP) and cognitive style

It is possible to observe in Figure 4 that in language there was no significant effect of cooperative learning methodology $(\mathrm{F}=$ $0,27 ; p=0,599)$, or of the cognitive style $(F=0,614 ; p=0,544)$.

Apparently cooperative learning benefits field independent participants in this area. It did not help the dependent field and had no effect on intermediates.

\subsection{Observation of the experience}

Students were receptive to the pedagogic proposal; they were interested in that process and they liked it. Throughout the display of the cooperative learning program it was noted that the students were able to strengthen work abilities that they already 
had, such as helping their partners, greeting, staying with the group, talking in a low voice, listening to teammates, calling students by their names, making a request courteously, expressing gratitude and asking for help.

In addition, they developed other group work skills. For instance, expressing ideas and opinions, asking questions, giving instructions to the group, cheering on their classmates, offering explanations, helping and motivating the group.

Regarding academic issues, benefit for students with high performance was evident because they performed as a guide and oriented their teammates, developing behaviors that could promote not only social but academic skills. Participants with low performance benefitted as well, because they had their classmate's help and also because they had the chance to be successful in activities and evaluations, achievements that would have been impossible without help. The "zone of proximal development”, as it was defined by Vygotsky (1978), was evidenced here.

The processing phase, which is a stage of the cooperative learning program where cooperative experiences are shared, helped them to develop the self-evaluation, self-regulation and self-monitoring processes. They learned how to recognize positive aspects not only in themselves but also in their partners, and they were mindful of the advantages of working and learning together.

\section{DISCUSSION}

Results of this study provide empirical evidence in favor of cooperative learning because the performance of students in math was superior in that methodology than in competitive and individualistic methodologies.

These findings support the theoretical proposal of Arias et al. (2003), Johnsons et al. (2008, 2014) and Slavin (1995), taking into account that cooperative learning could be a methodology which provides the greatest benefit in academic achievement for students compared to traditional methodologies. These findings also agree with research from Prayekti (2015), Peklaj (2013), Guerra \& Orozco (2009), Vidal (2012) and Vega et al. (2013).

Therefore, according to Johnsons and et al. (2008, 2014), it is possible to confirm that working in cooperative groups guarantees that all students assimilate in the best ways possible to the information and that group objectives motivates individual learning. Likewise, working in cooperative groups allows the development of several skills which hardly would appear in competitive and individualistic environments.

Keeping in mind that knowledge is socially built, according to Vygotsky (1978), it could be possible to think that cooperative learning provides elements to progress in learning processes. For this reason, Peklaj (2003) points out that cooperative learning gives a social frame needed for students to develop their skills.

Vega et al. (2013) provide another argument that could explain the positive effects of cooperative learning. They claim that when students interact in a cooperative learning situation, different levels of development of intellectual functions always converge, which promote that pairs with higher maturing pull on students with lower maturing. This interaction gives rise to what Vygotsky (1978) called "the zone of proximal development", which is a space that allows intellectual process to be developed with the help of pairs.

Considering effects related to the knowledge area, data showed that the cooperative learning program had a favorable impact on math achievement in the experimental group. These results support Peklaj (2003) and Guerra and Orozco's (2009) findings. However, the data does not suggest the same effect in language outcomes. This evidence seemed to indicate that math is a topic where cooperative learning shows full effect.

According to Serrano, Tejero \& Herrero (1997), "learning together”, a cooperative learning technique, has been widely used in math teaching because of its optimal results. Apparently, as it was postulated by Vega et al. (2013), the benefit showed by this teaching methodology in math could suggest that we are in the presence of a methodology which shows its effects only in some areas of knowledge. Consequently, it could be useful to identify which areas this methodology is more appropriate for. Possibly, those areas have different levels of demand or involve processes that require distinct interventions.

This effect could also be because of the difference in the kind of evaluation in every area. Whereas in math exact products are valued, in language qualitative progresses and individual effort are considered. Precisely, in the experimental group, some students showed lower levels of writing and reading. For this reason, it was necessary to do a personalized process and assess their individual progress inside the group.

Another factor that could imply that no benefits of cooperative learning in the language area was observed was the kind of activities or assignment carried out in each session of this subject. Maybe more emphasis should be placed on the importance of doing team activities in interaction with pairs. For instance, most of the reading activities are developed individually and pair participation was overlooked in this process. This is a factor to keep in mind in future research.

With regard to the effects related to cognitive tendency, the results are encouraging. Apparently, this methodology seems effective in every group of cognitive style in math.

It is important to keep in mind that the results of the pretest show that before pedagogical intervention, the dependent style group showed lower scores in math academic performance, the intermediate group had average results and the independent group showed better scores. This finding reflects the slant postulated by Hederich (2007), which says that our educational system favors the learning process of field independent individuals.

The cooperative learning program did not show any effect on any group of cognitive style in math. Therefore, it is possible to claim that it favored all participants regardless of cognitive tendency.

Perhaps, this is not only one of the most important findings but it is also controversial because previous studies present contradictory results. On the one hand, the results confirm what Tinajero et al. (2011) and Peklaj (2013) found and provide evidence in favor of this variable. On the other hand, the results do not confirm why in the reaserch done by Guerra \& Orozco (2009) or Vidal (2012) the results are opposite.

Despite these differences, the outcome of this work provides evidence in favor of cooperative learning as a pedagogical alternative that overtakes implicit limitations in traditional methodologies for field dependent students, at least in math.

The absence of the effect of cooperative learning on cognitive style groups highlights that this methodology allows all students to achieve learning purposes, decreasing disadvantages involved in other methodologies for the field dependent individuals. 
In the language area, the results suggest a slight effect of cooperative learning in favor of independent individuals. It is possible to think that in this area, cooperative learning strengthens characteristic skills of each cognitive style and for that reason that differentiation was observed.

This effect could be explained as follows. It is likely that independents may have assumed the tasks that implied more cognitive elaboration whereas dependents could have been more interested in organized information or in the preparation of academic products. This could suggest that independents tend to assume leadership roles inside cooperative teams and for that reason they end up being favored by cooperative work. This could also explain the results of Guerra \& Orozco (2009) and Vidal (2012) as well as the positive effects for field independents in math.

In a general perspective, it could be concluded that this study shows enough evidence to claim that cooperative learning is a methodology that has a positive impact on math, mainly, whereas in language there is no effect shown.

Besides, it is conceivable to claim that cooperative learning could be a methodological option that benefits all students regardless of their cognitive tendency, but only in math.

The purpose of future research could be to clarify the reason for these partial effects in order to define even more scopes and limitations of this pedagogical methodology.

\section{REFERENCES}

AbdelWahab Mahmoud, M. M. (2014). The Effectiveness of Using the Cooperative Language Learning Approach to Enhance EFL Writing Skills among Saudi University Students. Journal Of Language Teaching \& Research, 5(3), 616625. doi:10.4304/jltr.5.3.616-625

Ahmad, Z., \& Mahmood, N. (2010). Effecs of Cooperative Learning vs. Traditional Instruction on Prospective Teachers' Learning Experience and Achievement Journal of Faculty of Educational Sciences, 43(1), 151-164.

Arias, J., Roca, C., \& Estupiñán, F. (2003). Aprendizaje Cooperativo. Bogotá: Universidad Pedagógica Nacional.

Duxbury, J., \& Tsai, L. (2010). The Effects of Cooperative Learning on Foreign Language Anxiety: a Comparative Study of Taiwanese and American Universities. International Journal of Instruction, 3(1), 3-18.

García, M. (2012). Implementación de un programa de aprendizaje cooperativo y su efecto en el rendimiento en la resolución de problemas de estructura aditiva $y$ en el comportamiento asertivo de un grupo de estudiantes de diferente estilo cognitivo de $2^{\circ}$ de primaria. Unpublished master's thesis. Bogotá: Universidad Pedagógica Nacional.

Guerra, A., \& Orozco, N. (2009). Efectos del aprendizaje cooperativo en la resolución de problemas en estudiantes de diferente estilo cognitivo. Unpublished master's thesis. Bogotá: Universidad Pedagógica Nacional.

Haiyan, H. (2014). Transforming EFL Classes from Lecturing to Cooperative Learning. Journal Of Language Teaching \& Research, 5(4), 948-952. doi:10.4304/jltr.5.4.948-952 doi:10.4304/jltr.5.4.948-952

Hederich, C. (2007). Estilo Cognitivo en la dimensión Dependencia-Independencia de Campo. -Influencias culturales e implicaciones para la educación-. Bogotá: Universidad Pedagógica Nacional.

Herman, K. (2013). The Impact of Cooperative Learning on student engagement: Results from an Intervention. Active Learning Higher Education, 14(3), 175185. doi: $10.1177 / 1469787413498035$

Hossain, A., \& Ahmad, R. (2013). Effects of Cooperative Learning on Student's Achivement and Attitudes in Secondary Mathematics. Procedia - Social and Behavioral Sciences, 93, 473-477. doi:10.1016/j.sbspro.2013.09.222

Jiang, B. (2014). Web-based Cooperative Learning in College Chemistry Teaching. International Journal Of Emerging Technologies In Learning, 9(2), 45-47. doi:10.3991/ijet.v9i2.3224

Johnson, D. W., \& Johnson, R. T. (1999). Learning together and alone: Cooperative, competitive, and individualistic learning (5th ed.). Boston, MA: Allyn \& Bacon (First edition published 1975). doi:10.3102/0013189X09339057

Johnson, D. W., \& Johnson, R. T. (2009). An educational psychology success story: Social interdependence theory and cooperative learning. Educational Researcher, 38(5), 365-379

Johnson, D. W., Johnson, R. T., \& Holubec, E. J. (2008). Cooperation in the classroom (8th Ed.). Edina, MN: Interaction.
Johnson, D. W., Johnson, R. T., \& Smith, K. A. (2014). Cooperative Learning: Improving University Instruction by Basing Practice on Validated Theory. Journal On Excellence In College Teaching, 25(3/4), 85-118.

Khan, S. A., \& Ahmad, R. N. (2014). Evaluation of the Effectiveness of Cooperative Learning Method versus Traditional Learning Method on the Reading Comprehension of the Students. Journal Of Research \& Reflections In Education (JRRE), 8(1), 55-64.

Lavasani, M., \& Khandan, F. (2011). Mathematic Anxiety, Help Seeking Behavior and Cooperative Learning. Cypriot Journal of Educational Sciences, 6(2), 186193. doi:10.1016/j.sbspro.2011.03.085

López, O., \& Triana, S. (2013). Efecto de un activador computacional de autoeficacia sobre el logro de aprendizaje en estudiantes de diferente estilo cognitivo. Revista Colombiana de Educación, 64, 225-244.

MEN-ICFES (2003). Programa de evaluación de la educación básica. Pruebas Saber Lenguaje y Matemáticas Grado 3, 5, 7 y 9. Bogotá: Ministerio de Educación Nacional. Programa de Evaluación de la Educación Básica.

Monereo, C., \& Duran, D. (2002). Entramados. Métodos de aprendizaje cooperativo y colaborativo. Barcelona: Edebé.

Moreno, C. (2011). Efectos de un programa de aprendizaje cooperativo sobre el desarrollo de la escritura y la asertividad en niños de diferente estilo cognitivo. Unpublished master’s thesis. Bogotá: Universidad Pedagógica Nacional.

Muraya, D., \& Kimano, G. (2011). Effects of cooperative learning approach on biology mean achievement scores of secondary school student's in Machakos District, Kenya. Educational Research and Reviews, 6(12), 726-745.

Ning, H., \& Hornby, G. (2014). The Impact of Cooperative Learning on tertiary EFL Learner's Motivation. Educational Review, 66(1), 108-124. doi:10.1080/00131911.2013.853169

Peklaj, C. (2003). Gender, Abilities, Cognitive Style and Student's achievement in Cooperative Learning. Psiholoskaobzorja/Horizons of Psychology, 12(4), 9-22.

Pons, R., Prieto, M., Lomeli, C., Bermejo, M., \& Bulut, S. (2014). Cooperative Learning in Mathematics: a Study on the Effects of the parameter of equality on academic performance. Anales de Psicología, 30(3), 832-840. doi:10.6018/analesps.30.3.201231

Prayekti, M. (2015). The Influence Of Cooperative Learning Type STAD Vs Expository And Cognitive Style On Learning Of Comprehension Physics Concept In Among Students At Tenth Grade Senior High School In East Jakarta, Indonesia. Pinnacle Educational Research an Education 3(3), 1-9.

Sears, D., \& Pai, H. (2012). Effects of Cooperative versus Individual Study on Learning and Motivation after Reward-Removal. Journal of Experimental Education, 80(3), 246-262. doi:10.1080/00220973.2011.602372

Serrano, J., Tejero, M., \& Herrero, M. (1997). Aprendizaje cooperativo en matemáticas: un método de aprendizaje cooperativo-individualizado para la enseñanza de las matemáticas. Murcia: Universidad de Murcia.

Slavin R. (1995). Cooperative Learning: Theory, Research and Practice (2nd ed.). Boston: Allyn and Bacon.

Slavin, R., Sheard, P., Elliot, L., Chambers, B., \& Cheung, A. (2013). Effects of Cooperative Learning and Embedded Multimedia on Mathematics Learning in Key Stage 2: Final Report. Institute for Effective Education. The University of York.

Tinajero, C., Castelo, A., Guisande, A., \& Páramo, F. (2011). Adaptative Teaching and Field Dependence-Independence: Instructional Implications. Revista Latinoamericana de Psicología, 43(3), 497-510.

Vega, M., García, M., \& Vidal, D. (2013). Avances acerca de los efectos del aprendizaje cooperativo sobre el logro académico y las habilidades sociales en relación con el estilo cognitivo. Revista Colombiana de Educación, 64, 155174.

Vidal, C. (2012). Implicaciones del aprendizaje cooperativo en el rendimiento académico en matemáticas y en las habilidades sociales de estudiantes de diferente estilo cognitivo de grado quinto de básica primaria y grado sexto de básica secundaria. Unpublished master's thesis. Bogotá: Universidad Pedagógica Nacional.

Vygotsky, L. S. (1978). Mind society: The development of higher psychological processes. Cambridge, MA: Harvard University Press.

Witkin, H. A., Moore, C. A., Goodenough, D., \& Cox, P. H. (1977). FieldDependent and Field-Independent. Cognitive Styles and their Educational Implications. Review of Educational Research 47 (1), 1-64. doi:10.3102/00346543047001001

Zuo, W. (2011). The Effects of Cooperative Learning on Improving College Student's Reading Comprehension. Theory and Practice in Language Studies 1(8), 986-989. doi:10.4304/tpls.1.8.986-989 